\title{
A perspective for setting the research priorities for the productivity of future crop production in Finland
}

\begin{abstract}
JARI PELTONEN
PELTONEN, J. 1992. A perspective for setting the research priorities for the productivity of future crop production in Finland. Agric. Sci. Finl. 1: 361-366. (Univ. Helsinki, Dept. Plant Production, SF-00710 Helsinki, Finland.)

The author proposes that future research work on crop production should concentrate on alleviating the problems associated with overwintering and frost, early summer drought and rainy autumn in order to enhance the competitiveness of field crop production in Finland. Further, more detailed knowledge on the crops is required to understand the genotypic differences in potential yield formation in order to optimize management practices. Increasing the nitrogen $(\mathrm{N})$ fixation efficiency of leguminous species should be considered as an important target. Naked oats, sunflower, and leguminous plants might be advantageous species for future crop production in Finland. The bioenergetic implications of increasing crop productivity are discussed.
\end{abstract}

Key words: crop productivity, biochemical composition, bioenergetic cost, crop species

Crop production forms the basis of agriculture, i.e., there would be no agriculture without crop production. Therefore, when discussing the future of Finnish agriculture, crop production research has a significant role in maintaining the competitive position of Finnish agriculture.

The competitive position could be achieved through sustaining environmentally sound agriculture featuring economic productivity while maintaining high yield and good quality. Furthermore, production should involve limited risks, taking into account the biological factors in addition to the environmental ones. Thus, an understanding of management practices as well as crop physiology has a key role in sustainable agriculture as defined above. Crop research should primarily be carried out in field experiments because the interactions between the phenomena studied and the environment are emphasized in northern latitudes.

\section{Intensified productivity - a future prospect}

When adjusting to European integration, Finnish agricultural productivity must be considerably increased in order to improve competitiveness (KolA et al. 1992). Regarding crop production this can be attained either by breeding or more precise use of management practises. The improved productivity should result from optimization of inputs rather than increasing inputs (KURPPA 1992). The intensification of management practices by economical, technological and biological methods is efficient only if the genotype-dependent yield potential of a plant from sprouting to harvesting is known (Peltonen and Peltonen-Sainio 1991). Thus, more precise information is needed on the critical plant growth stages in which the management practices are most favourable (PELTONEN 1992 b). 
The ecological cropping systems probably have no future in Finland, because the use of inputs (no industrial inorganic fertilizers and pesticides allowed) in these cropping systems cannot be as controlled biologically as in the intensive cropping systems. Moreover, the quality of Finnish agricultural products is very high and they are free from pesticide residues according to international standards (Kumpulainen 1992). This is because only a limited number of pests and diseases are of importance in the marginal growing conditions prevailing in Finland (KARJALAINEN 1985). It is often claimed that yields cannot be sustained in monocultures based on repeated applications of inorganic fertilizers and pesticides. The Rothamsted long-term experiments in the U.K. during the period 1852 1986 showed, however, that they can (JENKINSON 1991), although these experiments also indicated the importance of crop rotation.

Within this context, resistance breeding in Finland has hardly ever resulted in significant yield improvements as has been the case in other European countries (KARJALAINEN 1985, DoODSON 1981). The geographical location of Finland offers, however, special challenges for crop production research, alleviating the problems associated with overwintering and frost, early summer drought, and rainy autumn (MUKULA and RANTANEN 1989 a,b,c). Further, more precise information is needed on the physiological traits underlying a good crop ideotype (Hovinen 1988 a, Peltonen-SAINIO 1991) and its adaptation to long day and low light intensity (Pulli 1988).

\section{The yield potential of cultivated crops}

In the present situation it is extremely important to identify which crop species can be economically produced in Finland in the future. The chemical composition of crop species varies greatly in their utility for either livestock, feedstock or "non-food" production. The amount of photosynthates needed by a crop is partly dependent on the chemical composition of the economic yield. In northern conditions, the ability of crops to convert light energy into biomass is, however, limited (ÅKERBERG and HAIDER 1976). Therefore, raising both quantity and quality simultaneously is increasingly difficult (Peltonen 1992 a).

In the following, the productivity of crop species is analyzed and drawn on the basis of their production related to the use of photosynthates. The results from the examination of the biochemical pathways (PENNING de VRIES et al. 1974) for the production of carbohydrates, proteins, and lipids from glucose were used as the basis. From 1 unit of glucose about 0.83 unit of carbohydrates, 0.40 unit of protein (assuming $\mathrm{NO}_{3}-\mathrm{N}$ to be the $\mathrm{N}$ source), or 0.33 unit of lipid could be produced. Based on these values it has been calculated how much energy produced in photosynthesis is consumed in the formation of the economic yield of certain crop species (Table 1). The nitrogen requirement of the crop was estimated by calculating the protein produced from available photosynthate (SINCLAIR and de WIT 1975 ), in addition to $\mathrm{N}$ required for $1 \%$ increase in the protein concentration (BHATIA and RABSON 1976).

To visualize more easily the differences between the crops, $\mathrm{N}$ requirements per gram of photosynthates were plotted against economic yield per gram of photosynthate (Fig. 1). In the lower right-hand part of Fig. 1 there are the carbohydrate rich crops (cereals, potato, sugar beet). Of all the plant species examied, the productivity, defined as conversion of photoassimilates into economic yield, is the highest in sugar beet and potato. In addition to their importance as food crops they have become increasingly important in "non-food" uses; starch is used for glue and as a binder in the paper industry. The alternative use of starch as a raw material in producing decomposed plastics is also increasing, especially as plastic mulch for agricultural purposes (DoAne 1981, Galliard 1986). The portion of domestic starch used as raw material for decomposed plastics is, however, only about $50 \%$ (Erikoiskasvitoimikunta 1987).

The fate of cereals in future Finnish crop production has received most attention because cereals are "bulk" products and over-produced in the world 


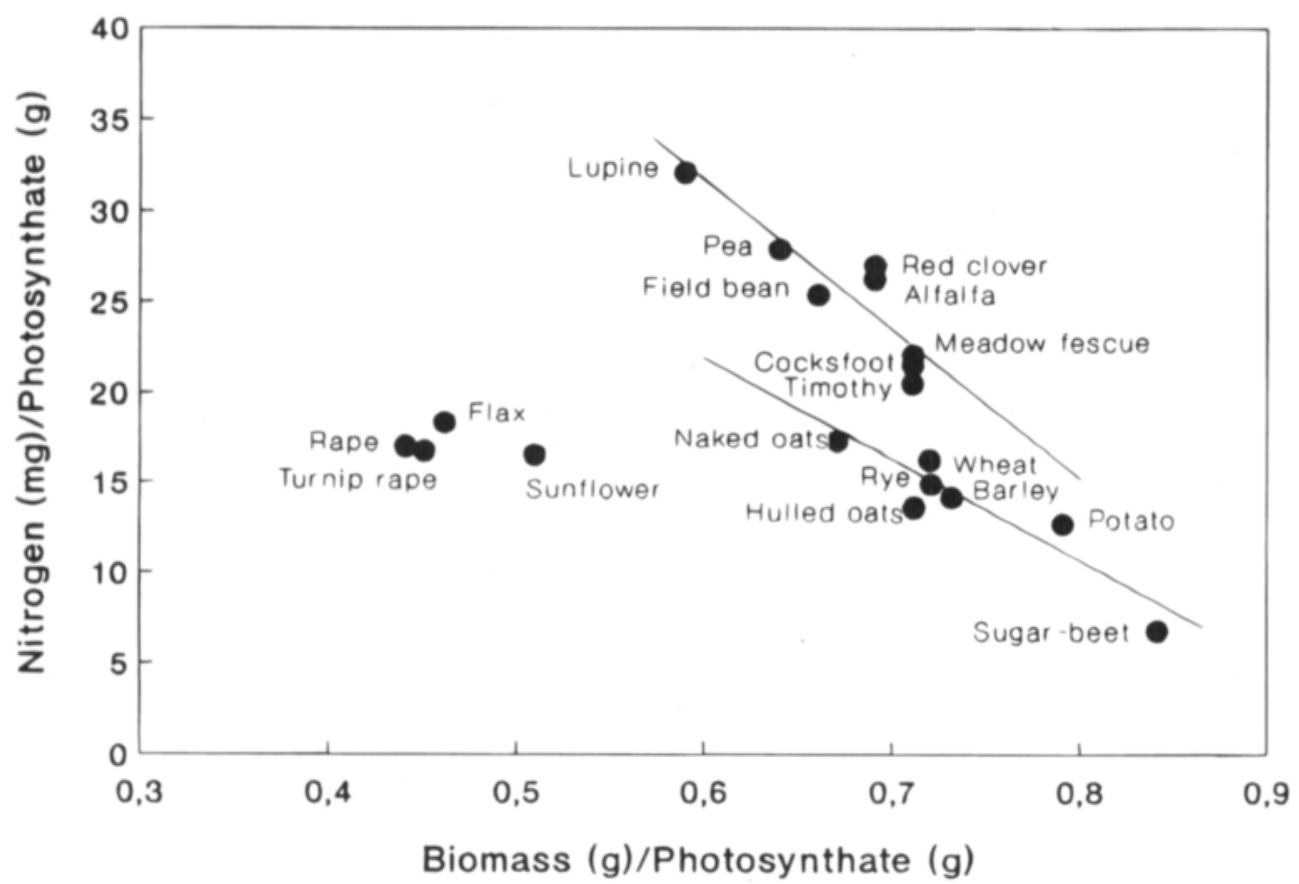

Fig. 1. The requirement of nitrogen $(\mathrm{mg})$ for yield per gram of available photosynthate $(\mathrm{g})$ for 19 crop species. Regression functions for protein crops $\mathrm{Y}=80.85-82.38 \mathrm{X}\left(\mathrm{R}^{2}=0.95^{* * *}\right)$, and for carbohydrate crops $\mathrm{Y}=54.49-55.26 \mathrm{X}\left(\mathrm{R}^{2}=0.96{ }^{* *}\right)$. There is no significant relationship between oil crop species.

market. In addition, it has been indicated that cereal production in particular suffers from the high production costs characteristic to of Finnish agriculture (KolA et al. 1992). Milk production has a better chance to adjust to European integration, but not without problems, either. As an alternative, the production of naked cereals such as wheat, rye and naked oats for feed (REKUNEN 1990) is suggested, because their feeding value is higher than that of ordinary hulled oats or barley. Naked oats is cultivated relatively little in the world. The probable reason for this is its poor yielding ability as compared with other cereals. The yield advantage of hulled oats without husks over the yield of naked oats is still approximately $600 \mathrm{~kg} \mathrm{ha}^{-1}$ (PELTONEN-SAINIO et al. 1992, manuscript). The limiting factor for the yield formation of naked oats is evidently the lower number of spikelets per panicle as compared with hulled oats (PeLtonen-SAINIO 1992, personal communication). Naked oats has, however, a clear advantage in industrial processing by saving the cost of hulling. Due to the "nakedness" of the grain the risk of harvesting damage increases (REKUNEN 1990). Lipid and protein contents are also high in naked oats (Table 1). Therefore, its yield formation requires more $\mathrm{N}$ fertilization than that of other cereals. The biological value of the protein in oats is not reduced by $\mathrm{N}$ fertilization as is the case in other cereals (LASZTITY 1984). Naked oats may be an alternative for cereal production in Finland following the advances in breeding for better yields.

In the lower left-hand part of Fig. 1 there are the oil crops (turnip rape, rape, flax, sun flower). Sunflower has the most effective yield formation of all of the oil crops. The reason for this may be its high potential maximum rate of leaf photosynthesis as compared to the other crops (PENNING de VRIES et al. 1989). Moreover, it requires less $\mathrm{N}$ for yield formation than turnip rape, rape or flax (Table 1). The high amount $(57 \%)$ of polyunsaturated fatty acids 
Table 1. Chemical composition, yield productivity (grams of biomass per gram of photosynthate), and nitrogen requirements (milligrams of $\mathrm{N}$ per gram of photosynthate) for crop yield of 19 crop species. Nitrogen requirement is calculated by assuming that protein is $16 \%$ nitrogen by weight. The last column gives the percentage increase in nitrogen requirement for a $1 \%$ increase in protein.

\begin{tabular}{|c|c|c|c|c|c|c|c|c|}
\hline & \multicolumn{4}{|c|}{$\begin{array}{l}\text { Composition*) } \\
\text { (\% of dry weight) }\end{array}$} & \multirow[b]{2}{*}{$\begin{array}{l}\text { Yield } \\
\text { productivity } \\
(\mathrm{g} / \mathrm{g})\end{array}$} & \multicolumn{3}{|c|}{$\begin{array}{l}\begin{array}{l}\text { Nitrogen requirement } \\
(\mathrm{mg} / \mathrm{g})\end{array} \\
\begin{array}{c}\text { increase } \\
\text { nitrogen }\end{array} \\
\end{array}$} \\
\hline & $\begin{array}{l}\text { Carbo- } \\
\text { hydrate }\end{array}$ & Protein & Lipid & Ash & & $\begin{array}{l}\text { With } \\
\text { standard } \\
\text { protein }\end{array}$ & $\begin{array}{l}\text { With } 1 \% \\
\text { increase } \\
\text { in protein }\end{array}$ & $(\%)$ \\
\hline Barley (Hordeum vulgare) & 83 & 12 & 2 & 3 & 0.73 & 14.1 & 15.3 & 8.5 \\
\hline Hulled oats (Avena sativa) & 80 & 12 & 5 & 3 & 0.71 & 13.6 & 14.7 & 8.1 \\
\hline Naked oats (Avena sativa) & 76 & 16 & 6 & 2 & 0.67 & 17.1 & 18.2 & 6.4 \\
\hline Potato (Solanum tuberosum) & 84 & 10 & 0 & 6 & 0.79 & 12.7 & 13.9 & 9.4 \\
\hline Rye (Secale cereale) & 83 & 13 & 2 & 2 & 0.72 & 15.0 & 16.2 & 8.0 \\
\hline Sugar-beet (Beta vulgaris) & 88 & 5 & 0 & 7 & 0.84 & 6.7 & 8.1 & 1.2 \\
\hline Wheat (Triticum aestivum) & 82 & 14 & 2 & 2 & 0.72 & 16.0 & 17.2 & 7.5 \\
\hline Alfalfa (Medicago sativa) & 61 & 24 & 4 & 11 & 0.69 & 26.4 & 27.5 & 4.2 \\
\hline Field bean (Vicia faba) & 70 & 24 & 2 & 4 & 0.66 & 25.5 & 26.6 & 4.3 \\
\hline Lupine (Lupinus sp.) & 58 & 34 & 5 & 3 & 0.59 & 32.0 & 32.9 & 2.9 \\
\hline Pea (Pisum sativum) & 68 & 27 & 2 & 3 & 0.64 & 27.8 & 28.8 & 3.6 \\
\hline Red clover (Trifolium pratense) & 60 & 24 & 4 & 12 & 0.69 & 26.6 & 27.7 & 4.1 \\
\hline Cocksfoot (Dactylis glomerata) & 70 & 19 & 3 & 8 & 0.71 & 21.4 & 22.6 & 5.6 \\
\hline Meadow fescue (Festuca pratensis) & 68 & 19 & 3 & 10 & 0.71 & 21.7 & 22.9 & 5.5 \\
\hline Timothy (Phleum pratense) & 71 & 18 & 3 & 8 & 0.71 & 20.5 & 21.6 & 5.4 \\
\hline Flax (Linum usitatissimum) & 33 & 25 & 38 & 4 & 0.46 & 18.4 & 19.1 & 3.8 \\
\hline Rape (Brassica napus) & 26 & 24 & 45 & 5 & 0.44 & 16.9 & 17.6 & 4.1 \\
\hline Sunflower (Helianthus annuus) & 48 & 20 & 29 & 3 & 0.51 & 16.4 & 17.2 & 4.9 \\
\hline Turnip rape (Brassica rapa) & 30 & 23 & 42 & 5 & 0.45 & 16.7 & 17.4 & 4.2 \\
\hline
\end{tabular}

*) Information taken from SALO et al. (1990), naked oats from PeltonEN-SAINIO et al. (1992), manuscript.

in sunflower seed oil is an indicator of its good quality for human consumption. In contrast, rape seed oil contains some $25 \%$ of polyunsaturated fatty acids (WEISS, 1983). The rhizosphere pattern of sunflower is strong and deep. It can efficiently take up nutrients which may enable production even without application of chemical fertilizers. Harvesting of sunflower may be difficult because the moisture content of the seed seldom falls below $20 \%$ (FAO 1985). The inclusion of hybrids in crossing programs has been shown to lead to positive results with early maturity, good oil content, disease resistance and lodging resistance in breeding sunflower cultivars for northern latitudes (DEDIO 1988).

In the upper right-hand part of Fig. 1 there are the protein rich crops (lupine, pea, field bean, red clover, alfalfa, and grasses). The productivity of lupine is lower than that of pea and field bean. Furthermore, the high content of alkaloids in lupine lessens its use as feed (Alaviuhrola 1986). Due to the high lysine content of pea and field bean (SALO et al. 1990), they have a high value in feeding. In breeding, more stable yield formation is obtained with the help of the $a f$ - and def-gene in pea and the $t i$-gene in field bean (Hovinen 1988 a,b). The 
increase of pea and field bean cultivation is thus recommended to substitute the imported soyabean for industry. Owing to their capacity for biological $\mathrm{N}$ fixation, leguminous plants such as pea, field bean, red clover and alfalfa are independent of inorganic $\mathrm{N}$ fertilizer. For this reason red clover and alfalfa have higher productivity than meadow fescue, cocksfoot, and timothy (Fig. 1). Many efforts have been made to improve the $\mathrm{N}$ fixation ability of Rhizobium bacteria (UOMALA 1986), but more detailed studies from this research area are still needed. A research priority could be to attempt to increase the resistance of $\mathrm{N}$ fixation bacteria to soil acidity and early summer drought.

\section{References}

Alaviuhkola, T. 1986. Onko lupiinilla käyttöå sikataloudessa. Käytännön Maamies 35: 55-57.

BhatiA, C.R. \& Rabson, R. 1976. Bioenergetic considerations in cereal breeding for protein improvement. Science 194: 1418-1421.

DEDIO, W. 1988. Breeding sunflower cultivars for the northern latitudes. J. Agric. Sci. Finl. 60: 255-259.

DOANE, W.D. 1981. Starch: Industrial raw material. In: Pomeranz \& Munck (eds.). Cereals: A Renewable Resource. St Paul. p. 265-290.

Doodson, J.K. 1981. The economic contribution of resistant winter wheat varieties. J. Natn. Inst. Agric. Bot. 15: 413420.

Erikoiskasvitoimikunta 1987. Erikoiskasvitoimikunnan mietintö. Komiteamietintö 33. Helsinki. 240 p.

FAO 1985. Equipment and methods for sunflower production. FAO Economic Comission for Europe. Agri/Mech Repr. 108. New York. 10 p.

GALliaRD, T. 1986. Bulk chemicals from plants: starch and starch derived products. In: Fuller \& Gallon (eds.). Plant Products and the New Technology. New York. p. 103105.

HOVINEN, S. 1988 a. Breeding of a protein pea ideotype for Finnish conditions. J. Agric. Sci. Finl. 60: 7-71.

- 1988 b. Breeding of field bean (Vicia faba L.) with early maturity. J. Agric. Sci. Finl. 60: 261-267.

JENKInSON, D.S. 1991. The Rothamsted long-term experiments: are they still of use. Agron. J. 83: 2-10.

KARJALAINEN, R. 1985. Kasvin resistenssi ja taudinkestävyysjalostus. Helsingin yliopiston kasvipatologian laitoksen monisteita n:o 8.88 p.

Kola, J., MartTILA, J. \& Niemi, J. 1992. Finnish agriculture in European integration: A firm level approach. Agric. Sci. Finl. 1: 5-14.

Kumpulainen, J. 1992. Kotimaisten ja ulkomaisten elintarvikkeiden puhtaus ja laatu. Maatal.tiet. päivăt, Helsinki. Mimeogr. [Available at Agric. Res. Centre of Finland, Food Res. Inst.]

KURPPA, S. 1992. Tuhoeläintorjunnan kustannusvaikutukset. Suom. Maatal.tiet. Seur. Tied. No 16. p. 68-76.

LASzTITY, R. 1984. The chemistry of cereal proteins. CRC Press, Inc. Boca Raton, Florida. 203 p.
Mukula, J. \& Rantanen, O. 1989 a. Climatic risks to the yield and quality of field crops in Finland. III. Rye. Ann. Agric. Fenn. 28: 3-11.

— \& RANTANEN, O. 1989 b. Climatic risks to the yield and quality of field crops in Finland. V. Spring wheat. Ann. Agric. Fenn. 28: 21-28.

— \& RANTANEn, O. 1989 c. Climatic risks to the yield and quality of field crops in Finland. VI. Barley. Ann. Agric. Fenn. 28: 29-36.

Peltonen, J. 1992 a. Influence of environment and genotype on spring wheat yield and bread-making quality under Finnish conditions. Acta Agric. Scand. 42: 111-117.

- 1992 b. Ear developmental stage used for timing supplemental nitrogen application to spring wheat. Crop Sci. 32: (in press)

— \& Peltonen-SAinio, P. 1991. Formation and abortion of florets of wheat and oat cultivars differing in duration of pre-anthesis and post-anthesis phases. Cereal Breeding. Proc. Eucarpia Cereal Sect. Meet., Schwerin. Sect. 4 Breeding Spec. Traits. p. 212.

Peltonen-SAinio, P. 1991. Productive oat ideotype for northern growing conditions. Euphytica 54: 27-32.

Penning de Vries, F.W.T., Brunstting, A.H.M. \& vanLAAR, H.H. 1974. Products, requirements and efficiency of biosynthesis: A quantitative approach. J. Theor. Biol. 45: 339-377.

—, JANSEN, D.M., ten Berge, H.F.M. \& BAKemA, A. 1989. Simulation of ecophysiological processes of growth in several annual crops. Pudoc Wageningen. $271 \mathrm{p}$.

Pulli, S. 1988. Adaptation of red clover to the long day environment. J. Agric. Sci. Finl. 60: 201-214.

REKUNEN, M. 1990. Kuoreton rehuvilja, realistinen vaihtoehto? Hankkijan kasvinjalostuslaitos. Siemenjulkaisu 1990. p. 98-101.

Salo, M.L., TuOrI, M. \& KiISKInEN, T. 1990. Rehutaulukot ja ruokintanormit. $70 \mathrm{p}$.

SINCLAIR, T.R. \& de WIT, C.T. 1975. Photosynthate and nitrogen requirements for seed production by various crops. Science 189: 565-567.

UOMALA, P. 1986. Biologinen typensidonta ja sen tehostus. SITRA Biologisen typensidonnan ja ravinnetypen hyväksikäytön projekti. Sitra ja Maatalouskeskusten 
Liitto. Tietolehtinen $1.8 \mathrm{p}$.

Weiss, E.A. 1983. Sunflower. Oilseed crops. p. 402-462.

ẢKERBERG, E. \& HAIDER, T.O. 1976. Climatic influence on yield for summer cereals grown under northern climatic conditions. J. Agron. \& Crop Sci. 143: 275-286.
Manuscript received May 1992

Jari Peltonen

University of Helsinki

Department of Plant Production

SF-00710 Helsinki, Finland

\section{SELOSTUS}

\section{Suomen kasvinviljelytutkimuksen painopisteitä tuotannon tehostamiseksi peltoviljelyssä

\author{
JARI Peltonen \\ Helsingin yliopisto
}

Kasvinviljelytutkimuksella on merkittåvä osuus Suomen maatalouden kilpailuaseman kehittämisessä. Meidän kasvinviljelymme keskeisiä tutkimusongelmia ovat talvenkestävyys, alkukesän poutaisuuteen ja korjuukauden sateisiin oloihin sopeutuvien lajikkeiden ja viljelymenetelmien kehittäminen. Viljelytoimenpiteiden tehostaminen niin taloudellis-teknologisen kuin biologisen tuotannon kannalta on kuitenkin tehokkaimmillaan vasta, kun tunnemme viljelykas- vien lajikekohtaisen sadonmuodostuspotentiaalin. Tämă tietö antaa selkeăn käsityksen siitä, missä kasvien kehitysvaiheessa eri viljelytoimenpiteet ovat välttämättömiä. Kuorettoman kauran, auringonkukan ja palkokasvien tutkimiseen tulisi kiinnittää entistä enemmän huomiota. Tutkimuksessa on pohdittu eri kasvilajien sadontuottokykyä ja typpitaloutta yhteyttämisesså tuotetun energian hyväksikäyttötehon perusteella. 